\title{
Genome Association Study for Visual Scores in Nellore Cattle Measured at Weaning
}

\author{
Luis Orlando Duitama Carreño ${ }^{1}$, Matilde da Conceição Pessoa', Rafael Espigolan', Luciana Takada' , Tiago Bresolin', \\ Ligia Cavani ${ }^{1 *}$ (D) Fernando Baldi ${ }^{1}$, Roberto Carvalheiro ${ }^{1}$, Lucia Galvão de Albuquerque ${ }^{1}$ and Ricardo da Fonseca ${ }^{2}$
}

\begin{abstract}
Background: Genome-wide association studies (GWAS) are utilized in cattle to identify regions or genetic variants associated with phenotypes of interest, and thus, to identify design strategies that allow for the increase of the frequency of favorable alleles. Visual scores are important traits of cattle production in Brazil because they are utilized as selection criteria, helping to choose more harmonious animals. Despite its importance, there are still no studies on the genome association for these traits. This study aimed to identify genome regions associated with the traits of conformation, precocity and muscling, based on a visual score measured at weaning.

Results: Bayesian approaches with BayesC and Bayesian LASSO were utilized with 2873 phenotypes of Nellore cattle for a GWAS. The animals were genotyped with Illumina BovineHD BeadChip, and a total of 309,865 SNPs were utilized after quality control. In the analyses, phenotype and deregressed breeding values were utilized as dependent variables; a threshold model was utilized for the former and a linear model for the latter. The association criterion was the percentage of genetic variance explained by SNPs found in $1 \mathrm{Mb}$-long windows. The Bayesian approach BayesC was better adjusted to the data because it could explain a larger phenotypic variance for both dependent variables.

Conclusions: There were no large effects for the visual scores, indicating that they have a polygenic nature; however, regions in chromosomes 1, 3, 5, 7, 14, 15, 16, 19, 20 and 23 were identified and explained a large part of the genetic variance.
\end{abstract}

Keywords: BayesC, Bayesian LASSO, Growth genes

\section{Background}

With the advent of bovine genome sequencing [1], new information has become available for the prediction of genetic values through genomic selection (GS) and to locate regions or associated genes with phenotypes of interest through genome-wide association studies (GWAS) [2, 3]. In GWAS analyses, simple regression models are frequently utilized, however, this method has two limitations. The first limitation is the overestimation of the variance proportion explained by a marker, once it does not consider the existing linkage disequilibrium

\footnotetext{
* Correspondence: ligiacavani@hotmail.com

${ }^{1}$ Animal Science Department, School of Agricultural and Veterinary Sciences,

São Paulo State University (Unesp), Jaboticabal, São Paulo, Brazil

Full list of author information is available at the end of the article
}

(LD) among markers [4]. The second limitation is the high rate of false positives when the population structure is not taken into consideration [5]. The use of Bayesian multiple regression models initially proposed for GS [6], such as Bayesian LASSO [7] and BayesC [8], overcomes these limitations.

The Bayesian approach differs with respect to a priori distribution for QTL (quantitative trait locus) effects. Bayesian LASSO assumes that there are few genes with large effects and many genes with small or no effects, whereas BayesC assumes that most SNPs (Single Nucleotide Polymorphisms) are not associated with phenotype, and only a small $\pi$ portion has some effect on traits. The best model depends on the trait genetic

(c) The Author(s). 2019 Open Access This article is distributed under the terms of the Creative Commons Attribution 4.0 International License (http://creativecommons.org/licenses/by/4.0/), which permits unrestricted use, distribution, and reproduction in any medium, provided you give appropriate credit to the original author(s) and the source, provide a link to the Creative Commons license, and indicate if changes were made. The Creative Commons Public Domain Dedication waiver (http://creativecommons.org/publicdomain/zero/1.0/) applies to the data made available in this article, unless otherwise stated. 
architecture, which is unknown, mainly when the traits have not been extensively studied [9].

In cattle, association studies have been carried out for most economically important traits [10-13]. However, GWAS have not yet been conducted for morphological traits evaluated through visual scores in beef cattle, which have a high relevance to Brazilian cattle breeding. The utilization of these traits by producers as selection criteria is important for the identification of harmonious animals and its correlation with economic interest traits, mainly those for growth [14-16] and those that indicate carcass quality [17-19].

In dairy cattle, the results of some association studies for linear evaluations of type, which assess several morphological traits [20-23], are already available. In general, these studies did not find regions with large effects, showing that morphological traits have a polygenic nature; that is, they are controlled by multiple genes with small effects [5]. The distribution of QTL effects for traits is a factor that influences the prediction accuracy of genomic breeding values and this accuracy is greater when there are large effect QTLs [5, 24].

Due to the importance of visual scores for Brazilian cattle breeding, it is desirable that the regions involved in the genetic control of these traits have pleiotropic effects on other important economic traits and that there are large effect QTLs, resulting in greater genetic gains when utilized as selection criteria. This study aimed to identify genome regions associated with the traits of conformation $(\mathrm{C})$, precocity $(\mathrm{P})$ and muscling $(\mathrm{M})$ visual scores, measured at the weaning of Nellore cattle, and to compare BayesC and Bayesian LASSO in a genomic association study.

\section{Methods}

\section{Ethics statement}

Data collection procedures were reviewed and approved by the Ethical Committee for Animal Care and Use (CEUA) of the São Paulo State University, UNESP - Jaboticabal, São Paulo, Brazil (protocol number: 18.340/16).

\section{Data set}

Data were used from Nellore males and females, born between 2007 and 2011, belonging to two animal breeding programs, DeltaGen and Paint, and including more than 250 farms distributed across Brazil. Although the animals were from two distinct programs, they had a similar objective selection for weaning and yearling weight, and several sires were common to both programs, which were used for artificial insemination service. A previous GWAS analysis on birth weight revealed that the animals from these two breeding programs clustered in the same group ("cluster 1") of a principal component analysis based on the genomic kinship coefficient [25].

Phenotypes for the visual scores were evaluated at weaning. Each contemporary group was assessed by a single technician. First, the whole herd was observed and characterized. Then, the average profile for each trait was used as a basis of comparison to attribute scores that varied from 1 to 5 , where 5 was the highest expression and 1 was the smallest expression. Each visual score was defined as [26]: conformation (C) estimates the amount of meat on the carcass by length, body depth and muscle development; precocity (P) represents the ability of the animal to display the lowest acceptable degree of finishing with a low body weight, considering rib depth and fat deposition at the groin and tail of the animals at the time of evaluation; muscling (M) measures the amount of muscular mass, using as a reference the muscular development in the shoulder, foreleg, loin, rump and hind.

A total of 2021 females and 1416 males with records for $\mathrm{C}, \mathrm{P}$ and $\mathrm{M}$ with genotypical information were utilized for the analyses. For genome association studies, the phenotype of visual scores and the deregressed breeding values (dEBV) were used as dependent variables for 2873 records after accounting for quality control and the smaller number of records for dEVBs (Table 1) as only animals with an accuracy over 0.60 were considered for inclusion.

Estimation of the breeding values (EBVs) of scores was done through a multi-trait threshold animal model, as described by [27]. Direct and maternal genetic, permanent environmental and residual effects were included as random effects, whereas contemporary group (farm, year of birth, management group at weaning, and sex) was used as a fixed effect and age at measurement was used as a co-variable (linear and quadratic effect). Genetic parameters and breeding values were estimated utilizing THRGIBBS1F90 software, which implements the Bayesian approach under a threshold model [28]. A total of 236,288 animals with phenotypes born from 1990 to 2012 and 300,484 animals included in the relationship matrix were used to estimate breeding values. EBV accuracy was calculated as described by [29] and deregressed breeding values were calculated using the methodology described by [30].

\section{Genotypic data}

The animals were genotyped with Illumina BovineHD BeadChip (Illumina, San Diego, CA, USA), according to the manufacturer's protocol. BovineHD BeadChip has 777,962 SNPs scattered throughout the genome with an average distance of $3.43 \mathrm{~kb}$ between markers. The inclusion criteria used to control genotype quality were: SNPs located in autosomes; call rate per SNP greater than 
Table 1 Number of records, according to the dependent variable, in genome association analyses for visual scores of conformation $(\mathrm{C})$, precocity $(\mathrm{P})$ and muscling $(\mathrm{M})$

\begin{tabular}{|c|c|c|c|c|c|c|c|c|c|}
\hline \multirow[t]{2}{*}{ Score } & \multirow{2}{*}{$\begin{array}{l}\text { Dependent } \\
\text { variable }\end{array}$} & \multicolumn{3}{|c|}{ Record } & \multicolumn{5}{|c|}{ Average/Frequency* } \\
\hline & & Males & Females & Total & 1 & 2 & 3 & 4 & 5 \\
\hline \multirow[t]{2}{*}{$C$} & Phenotype & 1977 & 896 & 2873 & 0.036 & 0.186 & 0.400 & 0.263 & 0.115 \\
\hline & dEBV & 1266 & 601 & 1867 & & & 0.232 & & \\
\hline \multirow[t]{2}{*}{$P$} & Phenotype & 1977 & 896 & 2873 & 0.040 & 0.164 & 0.355 & 0.279 & 0.162 \\
\hline & dEBV & 1132 & 569 & 1701 & & & 0.293 & & \\
\hline \multirow[t]{2}{*}{ M } & Phenotype & 1977 & 896 & 2873 & 0.055 & 0.184 & 0.363 & 0.246 & 0.152 \\
\hline & dEBV & 1118 & 553 & 1671 & & & 0.354 & & \\
\hline
\end{tabular}

$d E B V$ deregressed breeding value; *frequency for phenotypic values and averages for deregressed breeding values, dEBV

0.95; call rate per animal greater than 0.90 ; minor allele frequency greater than 0.05 ; $p$-value for Hardy-Weinberg equilibrium (HWE) test less than $1 \times 10^{-5}$ (extreme equilibrium deviations suggest potential genotyping errors). Highly co-related SNPs $\left(\mathrm{r}^{2}>0.98\right)$ were excluded. Quality control was an interactive process that stopped when no SNP or sample were excluded, resulting in 309,865 SNPs for analyses that considered phenotype as the dependent variable, and 308,861, 308,561 and 308,481 SNPs for C, P and M, respectively, when the dependent variable was $\mathrm{dEBV}$. Quality control and the input of missing genotypes were done with the snpStats package of $\mathrm{R}$ software [31].

\section{Association analyses}

Bayesian approaches BayesC and Bayesian LASSO were utilized to estimate marker effects. Both Bayesian approaches differ in their a priori distributions, which are assumed for marker effects. In general, the models can be presented in matrix notation as:

$$
Y=X \beta+Z \alpha+e
$$

where: $Y$ is a vector $\mathrm{n} \times 1$ of phenotype or dEBVs for the visual score of $\mathrm{C}, \mathrm{P}$ and $\mathrm{M} ; X$ is an $\mathrm{n} \times \mathrm{p}$ matrix that relates $\beta$ vectors of fixed effects with $Y ; Z$ is an $\mathrm{n} \times \mathrm{k}$ matrix of genotypes ( 0 for the first homozygote AA; 1 for the heterozygote $\mathrm{AB}$ or $\mathrm{BA} ; 2$ for the second homozygote $\mathrm{BB}$ ) of $\mathrm{k}$ SNPs; $\alpha$ is a $\mathrm{k} \times 1$ vector of random coefficients of regression for SNPs (an effect of allele substitution) and $e$ is a residual vector with a normal distribution $N \sim\left(0, I \sigma_{e}^{2}\right)$, where $\sigma_{e}^{2}$ is the residual variance, considered unknown with a scaled inverse Chi-square distribution [32].

The difference between Bayesian approaches is the a priori marginal distribution assumed for $\alpha$, which determines the variable selection and shrinkage in SNP effect estimates. For LASSO, the assumed distribution for effects is double-exponential. This distribution has a greater density at zero and thicker tails than a normal distribution, which causes an effect-dependent shrinkage because SNPs with small effects are regressed toward zero with greater shrinkage than the SNPs with large effects $[7,33]$. Shrinkage level is controlled by the $\lambda$ hyperparameter, which was inferred from data a priori using a Gamma distribution. For BayesC, the a priori effect distribution is a mixture at zero point mass and a normal distribution [8]. The proportion of SNPs with effects different from zero is controlled by the $\pi$ hyperparameter, which was fixed at 0.01 instead of being inferred from the data since [34] found convergence problems when the $\pi$ value was inferred from data. When score phenotype was considered a dependent variable, a threshold model with the probit function was utilized. The model assumes that there is a random variable subjacent to the observable phenotype, termed liability, which follows a standard normal distribution. The variance residual was fixed at 1 to make the estimation feasible. Fixed effects considered in the models were: contemporary group (formed by the management group at weaning, farm, birth year and sex) and weaning age, considered a co-variable. When dEVBs were the dependent variable, a linear model was utilized and only the average effect was considered a fixed effect in the model.

Analyses were carried out with the BGLR package of the software R [35], which implements Gibbs sampler to sample a posteriori parameter distributions. A total of 800,000 cycle chains were sampled. The first 200,000 were discarded as burn in and the remaining 600,000 samples were left for parameter inference.

\section{Association criterion}

With the use of a high-density chip, QTL effects can be distributed across several SNPs that are in LD with QTL, resulting in non-significant individual SNP effects [36, 37]; therefore, SNPs were grouped in $1 \mathrm{Mb}$-long windows, overlapping every $100 \mathrm{~kb}$, totaling 25,250 windows. The amount of SNPs per window varied from 1 to 336 , with an average of $122 \pm 25.2$ SNPs. The genetic variance percentage, explained by each window, was the criterion used to identify windows associated with scores; it was calculated as follows: 


$$
\% \sigma_{j}^{2}=\frac{\sigma_{j}^{2}}{\sigma_{S N P}^{2}} \frac{h^{2}}{h_{S N P}^{2}} 100
$$

where: $\% \sigma_{j}^{2}$ is the genetic variance percentage explained by window $j ; \sigma_{j}^{2}$ is the genetic variance explained by window $j ; \sigma_{S N P}^{2}$ is the genetic variance explained by SNPs; $h^{2}$ is the trait heritability and $h_{\text {SNP }}^{2}$ is the phenotypic variance proportion explained by markers (marker heritability). $\sigma_{j}^{2}$ and $\sigma_{S N P}^{2}$ were calculated as the variance of genomic breeding values (GEBV) of each window or the whole genome. GEBV for animal $i$ in window $j$ was calculated as:

$$
G E B V_{i j}=\sum_{k=1}^{K} X_{i k} \widehat{\alpha_{k}}
$$

where: $k$ is the number of SNPs within window $j ; \mathrm{X}_{\mathrm{ik}}$ is the genotype of animal $i$ for SNP $\mathrm{k}$ and $\alpha_{\mathrm{k}}$ is the allele substitution effect for SNP k. For 1 SNP windows, this method is equivalent to $2 p_{k}\left(1-p_{k}\right) \alpha_{k}^{2}$ [38]. The Bayesian approach that explained the greater proportion of phenotypic variance was chosen to identify genome regions associated with the phenotype; the genes for the windows that explained values above $0.25 \%$ of the additive genetic variance were identified, and a candidate gene was proposed as responsible for the variance explained by the window.

\section{Gene identification}

The database from the National Center for Biotechnology Information (NCBI) (http://www.ncbi.nlm.nih.gov/ snp/), loaded with bovine genome version UMD 3.1, was utilized to identify genes within the windows. Gene classification with respect to biological function was done through the Database for Annotation, Visualization and Integrated Discovery (DAVID) [39], available at http:// david.abcc.ncifcrf.gov/.

\section{Results}

In general, the proportion of phenotypic variance explained by SNPs was smaller than trait heritability. Moreover, BayesC explained the largest phenotypic variance and was nearest to heritability, and among the dependent variables, phenotype was superior to dEBVs. Table 2 also shows the number of windows that captured $10 \%$ of the genetic variance; in this criterion, BayesC with phenotype was superior, as well.

The identification of regions associated with visual scores was done through Bayes $\mathrm{C}$, utilizing phenotype as the dependent variable, because it was the Bayesian approach that best explained the proportion of phenotypic variance for all three visual scores. In Fig. 1 and Table 3, the windows that explained over $0.25 \%$ of the additive genetic variance for conformation, precocity and muscling are shown. Due to the great number of windows
Table 2 Proportion of phenotypic variance explained by BayesC and Bayesian LASSO and the number of windows needed to explain $10 \%$ of the genetic variance for the visual scores of

\begin{tabular}{|c|c|c|c|c|c|c|c|}
\hline Score & $h^{2}$ & Model & Dependent & $\sigma_{S N P}^{2}$ & $\sigma_{e}^{2}$ & $h_{S N P}^{2}$ & $10 \% \sigma_{a}^{2}$ \\
\hline \multirow[t]{4}{*}{ C } & 0.44 & BayesC & dEBV & 1.031 & 0.619 & $0.275[0.625]$ & 139 \\
\hline & & & Phenotype & 0.503 & 1.00 & 0.335 & 87 \\
\hline & & LASSO & dEBV & 0.970 & 0.711 & $0.254[0.577]$ & 175 \\
\hline & & & Phenotype & 0.412 & 1.00 & 0.292 & 101 \\
\hline \multirow[t]{4}{*}{ P } & 0.43 & BayesC & dEBV & 0.992 & 0.735 & $0.247[0.574]$ & 172 \\
\hline & & & Phenotype & 0.390 & 1.00 & 0.281 & 82 \\
\hline & & LASSO & dEBV & 0.824 & 0.921 & $0.203[0.472]$ & 198 \\
\hline & & & Phenotype & 0.322 & 1.00 & 0.244 & 99 \\
\hline \multirow[t]{4}{*}{ M } & 0.42 & BayesC & dEBV & 0.902 & 0.753 & $0.229[0.545]$ & 159 \\
\hline & & & Phenotype & 0.416 & 1.00 & 0.294 & 86 \\
\hline & & LASSO & dEBV & 0.850 & 0.834 & $0.212[0.504]$ & 205 \\
\hline & & & Phenotype & 0.355 & 1.00 & 0.262 & 104 \\
\hline
\end{tabular}
conformation (C), precocity $(\mathrm{P})$ and muscling $(\mathrm{M})$

$\mathrm{dEBV}=$ deregressed estimated breeding values; $\mathrm{h}^{2}=$ estimated heritability utilizing the threshold model; $\sigma_{\text {SNP }}^{2}=$ variance explained by SNPs; $\sigma_{e}{ }^{2}=$ residual variance; $h^{2}{ }_{\text {SNP }}=$ proportion of phenotypic variance explained by SNPs, values in brackets [] indicate the proportion related to additive genetic variance; $10 \%$ $\sigma_{a}{ }^{2}=$ number of windows that capture $10 \%$ of the genetic variance

that were necessary to explain $10 \%$ of the genetic variance, and just a few windows exceeding the threshold of $0.25 \%$, windows that were very close to the threshold were also included. For these windows, candidate genes responsible for the genetic variance explained by the window were proposed.

A total of 190 genes were located in 14 associated windows with the phenotype of visual scores: 150 genes were codified proteins, 16 were ncRNA (non-codifying RNA), 3 were miRNA (microRNA), 6 were tRNA (RNA transporter) and 15 were pseudogenes. In the identification of candidate genes, only genes that codify proteins were considered. Thus, 18 candidate genes were identified and classified into four groups according to the function that they perform in the organism: basal and cellular metabolism (TBC1D5, LPAR2, TMEM9, NDUFA13, GSTA3 and $F B X L 17)$, regulation and transcription of other genes (CREG1, POU2F1, MAPK11, MAPK12, ESRRG and STK3), lipid metabolism (SORL1 and ASCF2) and genes related to growth and skeletal muscle (C1QTNF3, PPP1R39, WFIKKN2 and IGFBP6). Furthermore, windows located in chromosomes 3 (0.4-14 Mb), 5 (118.7-119.7 $\mathrm{Mb}), 16(20.7-21.7 \mathrm{Mb})$ and $23(24.1-25.1 \mathrm{Mb})$ were associated with at least two scores (Table 3 ).

\section{Discussion}

The difference between the proportion of phenotypic variance explained by SNPs and trait heritability, a difference known as lost heritability [40], can be explained by several factors, such as the lack of LD among markers 

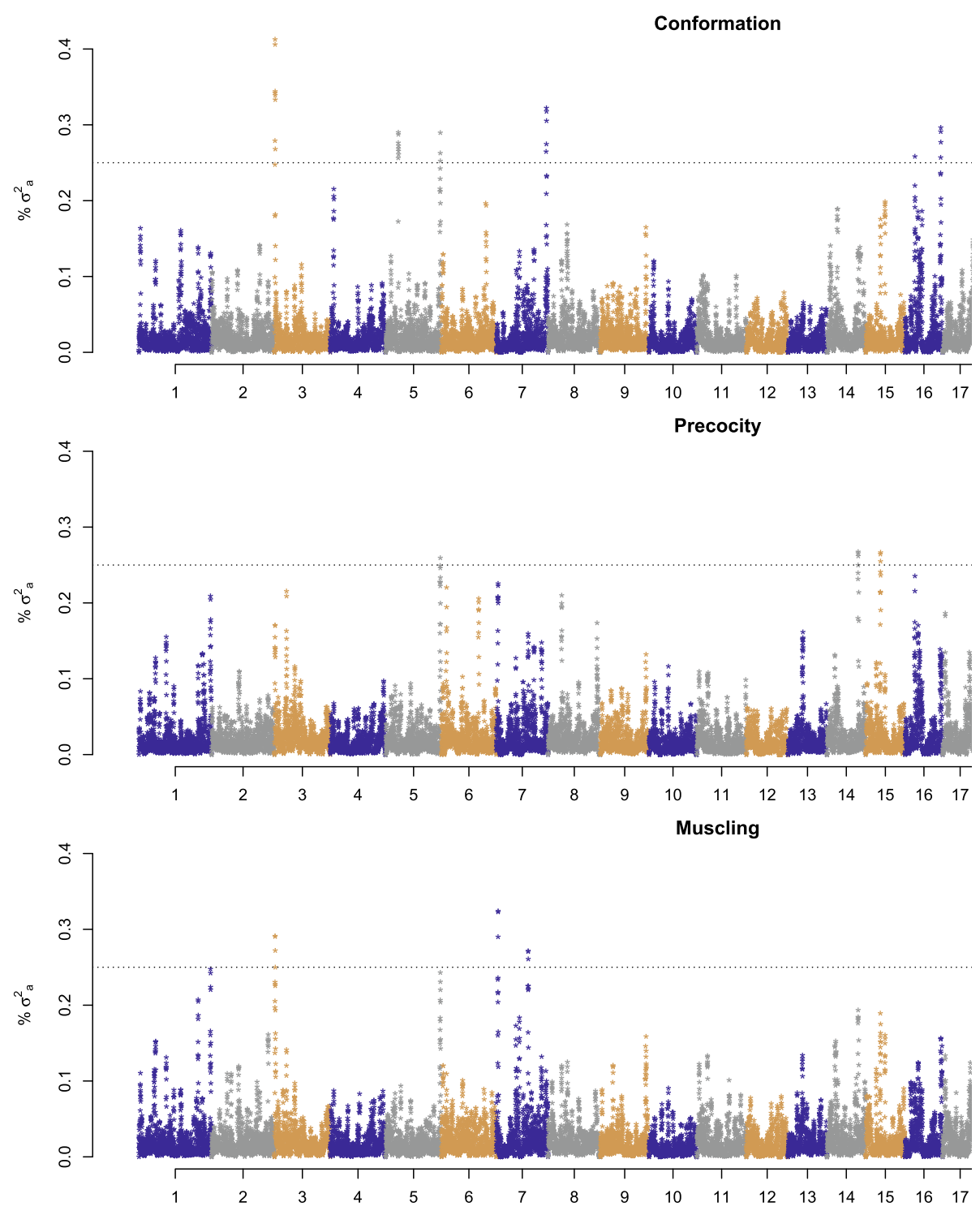

Fig. 1 Percentage of genetic variance explained by windows in each chromosome using the Bayesian approach BayesC, considering phenotype as the dependent variable of visual scores for conformation, precocity and muscling. Dotted lines mark the $0.25 \%$ threshold of genetic variance explained by the windows

and QTLs, interactions between variants, or interactions between genetics and the environment [41]. Another possible explanation could be the sample size, as it is necessary to increase the number of genotyped animals to capture small effect QTLs [42].

With respect to the Bayesian approaches used, BayesC had a better fit to the data as it was nearest to heritability and explained the largest phenotypic variance. In addition, phenotype was superior to dEBVs, although some authors have considered estimated breeding values (EBV) to be the best dependent variable for GWAS analyses [43] as they are the best estimate of genetic breeding value. The smallest phenotypic variance captured by the models that used dEBVs can be a consequence of a smaller number of animals used and a low estimation accuracy; once, $46 \%$ of genotyped animals only had one parent and 58\% did not have progeny, resulting in $75 \%$ of EBVs with an accuracy ranging from 0.60 to 0.70 .

The great number of windows needed to explain $10 \%$ of the genetic variance (Table 2) indicates that there are no large effect QTLs; therefore, the visual scores evaluated in Nellore cattle are influenced by many small effect genes, as reported for morphological traits in dairy cattle, in which large effect regions have not been identified, and the identified regions were not common among the studies [20-23].

The presence of genes related to basal and cellular metabolism, located in significant windows, is explained by 
Table 3 Gene identification and percentage of genetic variance explained by windows associated with visual scores for conformation (C), precocity (P) and muscling (M), utilizing BayesC, considering phenotype as the dependent variable

\begin{tabular}{|c|c|c|c|c|c|c|c|}
\hline \multirow[t]{2}{*}{ BTA } & \multirow[t]{2}{*}{$\mathrm{Mb}$} & \multicolumn{3}{|c|}{$\% \sigma_{a}^{2}$} & \multirow[t]{2}{*}{ Gene } & \multirow[t]{2}{*}{ Candidate } & \multirow[t]{2}{*}{ Description } \\
\hline & & C & $P$ & M & & & \\
\hline 1 & $155.9-156.9$ & & & 0.25 & 1 proteins & TBC1D5 & TBC1 domain family, member 5 \\
\hline 3 & $0.4-1.4$ & 0.41 & & 0.29 & $\begin{array}{l}10 \text { proteins } \\
1 \text { tRNA } \\
3 \text { pseudogenes }\end{array}$ & $\begin{array}{l}\text { CREG1 } \\
\text { POU2F1 }\end{array}$ & $\begin{array}{l}\text { Cellular repressor of E1A-stimulated; } \\
\text { POU class } 2 \text { homeobox } 1\end{array}$ \\
\hline 5 & $26.7-27.7$ & 0.29 & & & 30 proteins & IGFBP6 & Insulin-like growth factor protein 6 \\
\hline 5 & $118.7-119.7$ & 0.29 & 0.26 & 0.24 & $\begin{array}{l}3 \text { proteins } \\
4 \text { ncRNA }\end{array}$ & MAPK11 MAPK12 & Mitogen-activated protein kinase 11 and 12 \\
\hline 7 & $3.0-4.0$ & & & 0.32 & $\begin{array}{l}23 \text { proteins } \\
5 \text { pseudogenes } \\
2 \text { ncRNA }\end{array}$ & $\begin{array}{l}\text { LPAR2 } \\
\text { NDUFA13 }\end{array}$ & $\begin{array}{l}\text { Lysophosphatidic acid receptor } 2 ; \\
\text { NADH dehydrogenase } 1 \text { alpha, } 13\end{array}$ \\
\hline 7 & $59.0-60.0$ & & & 0.27 & $\begin{array}{l}9 \text { proteins } \\
2 \text { ncRNA }\end{array}$ & PPP1R39 & $\mathrm{SH} 3$ domain ring finger 2 \\
\hline 7 & 108.8-109.8 & 0.32 & & & $\begin{array}{l}2 \text { proteins } \\
1 \text { tRNA } \\
1 \text { ncRNA }\end{array}$ & FBXL17 & F-Box And Leucine-Rich Repeat Protein 17 \\
\hline 14 & $67.5-68.5$ & & 0.27 & & $\begin{array}{l}11 \text { proteins } \\
1 \text { tRNA } \\
2 \text { nCRNA }\end{array}$ & STK3 & Serine/threonine kinase 3 \\
\hline 15 & $31.7-32.7$ & & 0.27 & & $\begin{array}{l}5 \text { proteins } \\
1 \text { miRNA }\end{array}$ & SORL1 & Sortilin-related receptor, L(DLR class) \\
\hline 16 & $20.7-21.7$ & 0.26 & 0.24 & & $\begin{array}{l}2 \text { proteins } \\
1 \text { tRNA }\end{array}$ & ESRRG & Estrogen-related receptor gamma \\
\hline 16 & $80.7-81.7$ & 0.30 & & & 7 proteins & TMEM9 & Transmembrane protein 9 \\
\hline 19 & $36.0-37.0$ & & 0.23 & & $\begin{array}{l}23 \text { proteins } \\
3 \text { ncRNA } \\
4 \text { pseudogenes }\end{array}$ & $\begin{array}{l}\text { WFIKKN2 } \\
\text { ACSF2 }\end{array}$ & $\begin{array}{l}\text { Follistatin/kazal, immunoglobulin, kunitz and } \\
\text { netrin domain; Hypothetical protein LOC768237 }\end{array}$ \\
\hline 20 & $39.4-40.4$ & & & 0.26 & $\begin{array}{l}8 \text { proteins } \\
1 \text { tRNA }\end{array}$ & C1QTNF3 & C1q factor related protein 3 \\
\hline 23 & $24.1-25.1$ & & 0.35 & 0.24 & $\begin{array}{l}16 \text { proteins } \\
1 \text { tRNA } \\
2 \text { ncRNA } \\
2 \text { miRNA } \\
3 \text { Pseudogene }\end{array}$ & GSTA3 & Glutathione S-transferase, alpha 3 \\
\hline Total & & 1.87 & 1.62 & 1.87 & & & \\
\hline
\end{tabular}

BTA bovine chromosome, $M b$ window position in megabases; $\% \sigma_{a}{ }^{2}=\%$ of genetic variance explained by each window

the fact that these genes act on several tissues, affecting cell and body development as a whole and, therefore, contributing to general performance. These genes have an important pleiotropic effect because they are non-specific tissues that act on several body cells and metabolic pathways, which include: signaling among cells, protein synthesis and transportation, cell proliferation and survival, and transportation and formation of cell membrane and its receptors. The gene protein NDUFA13 (also known as GRIM-19) is found in this gene group and it is a functional component of mitochondrial complex I, which is also involved in apoptosis and cellular energy production processes [44]; modifications in this gene could cause lower energy availability for cellular processes, decreasing tissue growth. Another example is gene FBXL17, which intervenes in protein recycling processes in part of proteosoma $26 \mathrm{~S}$, acting on several cellular processes. This gene is expressed at different levels in the skeletal muscle of bovines from 8 to 12 months old, indicating that it is associated with muscle development at this age [45].

Genes that regulate transcription can be divided into two subgroups: one formed by the genes STK3, MAPK11 and $M A P K 12$, which belong to the kinase family (serine/ threonine-protein subgroup), and another that includes genes POU2F1, CREG1 and ESRRG, whose main function is to modulate genetic expression (transcription factor).

Kinases are enzymes that catalyze protein phosphorylation through the transfer of the ATP phosphoryl group, changing protein configuration and resulting in its activation or inactivation. Kinases represent the largest 
protein family in eukaryotes and are involved in multiple cellular processes, including cellular signaling mechanisms and the activation of transcription factors [46]. The gene STK3 (known in humans as MST2) acts as a repressor of genes involved in the fat deposition of Hanwoo bovines; the high expression levels of this gene have been associated with a low level of intramuscular fat, showing that this gene inhibits adipocyte proliferation [47]. The genes MAPK11 and MAPK12 are part of the metabolic pathway p38 MAPK, which is a preserved mechanism of cellular response to a broad variety of extracellular signals, and is proposed as a regulator of cellular differentiation, proliferation and development [48]. As p38 MAPK is not tissue-specific, it would explain why this region was associated with the phenotype for all three visual scores.

In the second subgroup, genes POU2F1 and CREG1 are transcription factors that regulate the activity of multiple genes that act on several metabolic pathways; among them are genes involved in growth, proliferation and cellular differentiation processes. POU2F1 was identified by [49] as one of the transcription factors that regulates the genes associated with the traits of growth and fat deposition in Iberian $x$ Landrace pigs, whereas [50] found differences in the genic expression level of CREG1 in the psoas major and flexor digitorium muscles of bovines, indicating that both genes act on the skeletal muscles and fat tissue. Gene ESRRG is a member of the receptor family related to estrogen (ESRR) that act as transcription activators for gene PERM1, involved in the energy metabolism of skeletal and cardiac muscle [51], making this gene associated with deposition in fat and muscle tissue.

Both genes involved in lipid metabolism were associated with the precocity score, which evaluates the animal's capacity to deposit fat. Gene SORL1 belongs to the low-density lipoprotein receptor family (LDLR) involved in cholesterol metabolism, whereas ACSF2 is associated with lipid metabolism and adipocyte differentiation. These two genes have been associated with intramuscular fat deposition in swine and bovines [52, 53].

Out of the four genes related to growth, three were associated with precocity and muscling, and the miostatin gene (GDF8) region did not show an association with visual scores. The miostatin gene is important in muscular development and is one of the genes responsible for the presence of double musculature in breeds like the Belgian Blue and Limousin. Gene PPP1R39 (also known as $S H 3 R F 2$ ), like the miostatin gene, negatively regulates muscular tissue growth once low expression levels are associated with muscular hypertrophy. Studying fast and slow growth lines in broiler chickens [54], found out that a deletion had been fixed for gene SH3RF2 in the fast growth line, and it was identified as the cause of the largest growth. In bovines [55], found out that this gene was under selection in the Blonde d'Aquitane breed, and was one of the genes responsible for the double muscle presence in animals.

Gene WFIKKN2 is an inhibitory protein of genes GDF8 (miostatin) and GDF11, involved in muscular development, leading the overexpression of this gene to produce muscular hypertrophy, as the miostatin gene negatively regulates muscular growth, as observed in rats and sheep [56, 57]. Genes IGFBP6 and C1QTNF3 positively regulate muscular growth in bovines and high expression levels are associated with cellular growth in skeletal muscles. Gene C1QTNF3 is also involved in subcutaneous and intramuscular fat deposition $[58,59]$.

Windows located in chromosomes 3, 5, 16 and 23 were associated with at least two scores; this was expected since the genetic correlations among the traits were high, ranging from 0.80 to 0.92 , indicating that the same genes were controlling the visual scores. The results of this study will help the selection process as the increase of favorable allele frequencies for identified genes will lead to greater genetic gains in visual scores.

\section{Conclusions}

According to our results, visual scores have a polygenic nature because regions explaining a great percentage of the genetic variance were not found. However, DNA regions associated with visual scores were identified, containing genes that are part of important biological processes and molecular functions in body development.

\section{Abbreviations}

C: Conformation; dEBV: deregressed breeding values; EBV: Breeding values; GEBV: Genomic breeding values; GS: Genomic selection; GWAS: Genomewide association studies; HWE: Hardy-Weinberg equilibrium; LD: Linkage disequilibrium; M: Muscling; P: Precocity

\section{Acknowledgements}

Not applicable.

\section{Funding}

This study was supported by a grant from the São Paulo State Foundation (FAPESP) no. 2009/16118-5. The funding body did not have any role in the study design, data collection, analysis and interpretation, the writing of the manuscript, or any influence on the content of the manuscript.

\section{Availability of data and materials}

Our research was accomplished using data from commercial farms and Nellore breeding programs. The data owners did not allow us to share the data because of their commercial interests in this data, especially in relation to the pedigree and genotype files. However, we can make all the files of our analyses available. These files refer to solutions from the GWAS analysis, which do not require any pedigree, phenotype or genotype file for post-GWAS analysis. They contain relevant information, such as trait, effect, start and end SNP number, SNP window size, chromosome position for the window (start and end), variance explained by each SNP window and other variances.

\section{Authors' contributions}

LODC, FB, RC, LGA, and RF were responsible for the data analyses; LODC, LC, $M C P, R E, L T$, and $T B$ were involved in data collection and were the main authors who wrote the ideas and interpreted the results for the manuscript. All authors read and approved the final manuscript. 


\section{Ethics approval}

Data collection procedures were reviewed and approved by the Ethical Committee for Animal Care and Use (CEUA) of the São Paulo State University, UNESP - Jaboticabal, São Paulo, Brazil (protocol number: 18.340/16).

\section{Consent for publication}

Not applicable.

\section{Competing interests}

The authors declare that they have no competing interests.

\section{Publisher's Note}

Springer Nature remains neutral with regard to jurisdictional claims in published maps and institutional affiliations.

\section{Author details}

'Animal Science Department, School of Agricultural and Veterinary Sciences, São Paulo State University (Unesp), Jaboticabal, São Paulo, Brazil. ${ }^{2}$ Animal Science Department, São Paulo State University (Unesp), Dracena, São Paulo, Brazil.

Received: 17 November 2017 Accepted: 7 February 2019 Published online: 20 February 2019

\section{References}

1. Elsik CG, Tellam RL, Worley KC, et al. The genome sequence of taurine cattle: a window to ruminant biology and evolution. Science. 2009;324:522-8.

2. Hayes B, Goddard M. Genome-wide association and genomic selection in animal breeding. Genome. 2010;53:876-83.

3. Dekkers JC. Application of genomics tools to animal breeding. Curr Genomics. 2012;13:207-12.

4. Gianola D, Verrier E, Verrier E. Contribution of an additive locus to genetic variance when inheritance is multi-factorial with implications on interpretation of GWAS. Theor Appl Genet. 2013;126:1457-72.

5. Hayes BJ, Pryce J, Chamberlain AJ, Bowman PJ, Goddard ME. Genetic architecture of complex traits and accuracy of genomic prediction: coat colour, milk-fat percentage, and type in Holstein cattle as contrasting model traits. PLoS Genet. 2010;6:e1001139.

6. Meuwissen THE, Hayes BJ, Goddard ME. Prediction of total genetic value using genome-wide dense marker maps. Genetics. 2001;157:1819-29.

7. Park T, Casella G. The bayesian LASSO. J Am Stat Assoc. 2008;103:681-6.

8. Habier D, Fernando RL, Kizilkaya K, Garrick DJ. Extension of the bayesian alphabet for genomic selection. BMC Bioinformatics. 2011;12:1-12.

9. González-Recio O, Forni S. Genome-wide prediction of discrete traits using bayesian regressions and machine learning. Genet Sel Evol. 2011;43:1-12.

10. Goddard ME, Hayes BJ. Mapping genes for complex traits in domestic animals and their use in breeding programmes. Nat Rev Genet. 2009;10: 381-91.

11. Bolormaa S, Hayes B, Savin K, Hawken R, Barendse W, Arthur P, et al. Genome-wide association studies for feedlot and growth traits in cattle. J Anim Sci. 2011;89:1684-97.

12. Hawken R, Zhang Y, Fortes M, Collis E, Barris W, Corbet N, et al. Genomewide association studies of female reproduction in tropically adapted beef cattle. J Anim Sci. 2012;90:1398-410.

13. Utsunomiya YT, Carmo AS, Neves HH, Carvalheiro R, Matos MC, Zavarez LB, et al. Genome-wide mapping of loci explaining variance in scrotal circumference in Nellore cattle. PLoS One. 2014;9:e88561.

14. Faria CU, Magnabosco CU, Albuquerque LG, Bezerra LAF. Estimativas de correlações genéticas entre escores visuais e características de carcaça medidas por ultrassonografia em bovinos Nelore utilizando modelos bayesianos linear-limiar. Rev Bras Zootec. 2009;38:2144-51.

15. Koury Filho W, Albuquerque LG, Forni S, Silva J, Yokoo MJ, Alencar MM. Estimativas de parâmetros genéticos para os escores visuais e suas associações com peso corporal em bovinos de corte. Rev Bras Zootec. 2010; 39:1015-22.

16. Boligon AA, Albuquerque LG. Correlações genéticas entre escores visuais e características reprodutivas em bovinos Nelore usando inferência bayesiana. Pesqui Agropecu Bras. 2010:45:1412-8.

17. Yokoo MJ, Werneck JN, Pereira MC, Albuquerque LG, Filho WK. Correlações genéticas entre escores visuais e características de carcaça medidas por ultrassom em bovinos de corte. Pesqu Agropec Bras. 2009;44:197-202.
18. Faria CU, Magnabosco CU, Albuquerque LG, De los Reyes A, LAF B, Lôbo RB. Estimativas de correlações genéticas entre escores visuais e características de crescimento em bovinos da raça Nelore utilizando modelos bayesianos linear-limiar. Ciência Animal Brasileira. 2008:9:327-40.

19. Gordo DM, Baldi F, Lôbo RB, Filho WK, Sainz RD, Albuquerque LG. Genetic association between body composition measured by ultrasound and visual scores in brazilian Nelore cattle. J Anim Sci. 2012;90:4223-9.

20. Kolbehdari D, Wang Z, Grant J, Murdoch B, Prasad A, Xiu Z, et al. A wholegenome scan to map quantitative trait loci for conformation and functional traits in Canadian Holstein bulls. J Dairy Sci. 2008;91:2844-56.

21. Alam M, Lee Y, Park B, Kim J, Lee S, Shin H, et al. A whole genome association study to detect single nucleotide polymorphisms for body conformation traits in a Hanwoo population. Asian-Australas J Anim Sci. 2011;24:322-9.

22. Cole JB, Wiggans GR, Ma L, Sonstegard TS, Lawlor TJ, Crooker BA, et al. Genome-wide association analysis of thirty one production, health, reproduction and body conformation traits in contemporary US Holstein cows. BMC Genomics. 2011;12:1-17.

23. Wu X, Fang M, Liu L, Wang S, Liu J, Ding X, et al. Genome wide association studies for body conformation traits in the Chinese Holstein cattle population. BMC Genomics. 2013;14:1-10.

24. Goddard M. Genomic selection: prediction of accuracy and maximization of long term response. Genetica. 2009;136:245-57.

25. Utsunomiya YT, Carmo AS, Carvalheiro R, Neves HR, Matos MC, Zavarez LB, et al. Genome-wide association study for birth weight in Nellore cattle points to previously described orthologous genes affecting human and bovine height. BMC Genet. 2013;14:52.

26. Júnior JJ, Pita FV, Fries LA, Albuquerque LG. Influência de alguns fatores de ambiente sobre os escores de conformação, precocidade e musculatura à desmama em um rebanho da raça Nelore. Rev Bras Zootec. 2001;30:1697-703.

27. Mrode RA. Linear models for the prediction of animal breeding values. [S.I.]: Cabi; 2005.

28. Misztal I, Tsuruta S, Strabel T, Auvray B, Druet T, Lee D, et al. BLUPF90 and related programs (BGF90). In: World congress on genetics applied to livestock production, 7th., 2002. Montpeller: Proceedings ... [S.I.]: Institut National de la Recherche Agronomique (INRA); 2002. p. 1-2.

29. González-Recio O, Chang YM, Gianola D, Weigel KA. Comparison of models using different censoring scenarios for days open in spanish Holstein cows. Anim Sci. 2006;82:233-9.

30. Garrick DJ, Taylor JF, Fernando RL, et al. Deregressing estimated breeding values and weighting information for genomic regression analyses. Genet Sel Evol. 2009;41:1-8.

31. Clayton D. snpStats: SnpMatrix and XSnpMatrix classes and methods. [S.I.]. R package version 1.14.0. 2013.

32. Fernando RL, Garrick D. Bayesian methods applied to GWAS. In: Genome Wide Association Studies and Genomic Prediction. [S.I.]: Springer; 2013. p. 237-74.

33. Gianola D. Priors in whole-genome regression: the bayesian alphabet returns. Genetics. 2013;194:573-96.

34. Berg IVD, Fritz $S$, Boichard D. QTL fine mapping with BayesC (pi): a simulation study. Genet Sel Evol. 2013;45:1-11.

35. de los Campos G, Perez RP. BGLR: Bayesian Generalized Linear Regression. [S.I.]. $R$ package version 1.0.2. 2013; http://CRAN.R-project.org/package=BGLR

36. Boddicker N, Waide E, Rowland R, Lunney J, Garrick D, Reecy J, et al. Evidence for a major QTL associated with host response to porcine reproductive and respiratory syndrome virus challenge. J Anim Sci. 2012;90:1733-46.

37. Onteru S, Fan B, Du ZQ, Garrick D, Stalder K, Rothschild M. A whole-genome association study for pig reproductive traits. Anim Genet. 2012;43:18-26.

38. Falconer DS, Mackay TF. Introduction to quantitative genetics. 4th ed. England: PERSON Prentice Hall; 1996.

39. Dennis JRG, Sherman BT, Hosack DA, Yang J, Gao W, Lane HC, et al. David: database for annotation, visualization, and integrated discovery. Genome Biol. 2003;4:R60.

40. Manolio TA, Collins FS, Cox NJ, Goldstein DB, Hindorff LA, Hunter DJ, et al. Finding the missing heritability of complex diseases. Nature. 2009;461:747-53.

41. Eskin E. Discovering genes involved in disease and the mystery of missing heritability. Commun ACM. 2015;58:80-7.

42. Wood AR, Esko T, Yang J, Vedantam S, Pers TH, Gustafsson S, et al. Defining the role of common variation in the genomic and biological architecture of adult human height. Nat Genet. 2014;46:1173-86. 
43. Becker D, Wimmers K, Luther H, Hofer A, Leeb T. A genome-wide association study to detect QTL for commercially important traits in Swiss Large White boars. PloS One. 2013;8:e55951.

44. Fearnley IM, Carroll J, Shannon RJ, Runswick MJ, Walker JE, Hirst J. GRIM-19, a cell death regulatory gene product, is a subunit of bovine mitochondrial NADH: ubiquinone oxidoreductase (complex i). J Biol Chem. 2001;276: 38345-8.

45. Sadkowski T, Jank M, Oprzadek J, Motyl T. Age-dependent changes in bovine skeletal muscle transcriptomic profile. J Physiol Pharmacol. 2006;57: 95-110.

46. Manning G, Whyte DB, Martinez R, Hunter T, Sudarsanam S. The protein kinase complement of the human genome. Science. 2002;298:1912-34.

47. Lee SH, van der Werf J, Kim NK, Lee SH, Gondro C, Park EW, et al. QTL and gene expression analyses identify genes affecting carcass weight and marbling on BTA14 in Hanwoo (korean cattle). Mamm Genome. 2011;22: 589-601.

48. Seger R, Krebs EG. The mapk signaling cascade. FASEB J. 1995;9:726-35.

49. Pérez-Montarelo D, Madsen O, Alves E, Rodríguez MC, Folch JM, Noguera JL, et al. Identification of genes regulating growth and fatness traits in pig through hypothalamic transcriptome analysis. Physiol Genomics. 2014;46: 195-206.

50. Moreno-Sánchez N, Rueda J, Carabaño MJ, Reverter A, Mcwilliam S, González C, et al. Skeletal muscle specific genes networks in cattle. Funct Integr Genomics. 2010;10:609-18.

51. Cho Y, Hazen BC, Russell AP, Kralli A. Peroxisome proliferator-activated receptor $\gamma$ coactivator 1 (pgc-1)-and estrogen-related receptor (err)-induced regulator in muscle 1 (perm1) is a tissue-specific regulator of oxidative capacity in skeletal muscle cells. J Biol Chem. 2013;288:25207-18.

52. Wang $H$, Zheng $Y$, Wang $G, L i H$. Identification of microma and bioinformatics target gene analysis in beef cattle intramuscular fat and subcutaneous fat. Mol BioSyst. 2013;9:2154-62.

53. Neustaeter A, Grossi D, Jafarikia M, Sargolzaei M, Schenkel F. Genome-wide association study for loin marbling score in Canadian Duroc pigs. In: WORLD CONGRESS OF GENETICS APPLIED TO LIVESTOCK PRODUCTION, 10th., 2014, Vancouver, BC. Proceedings... Vancouver: World Congress of Genetics Applied to Livestock Production; 2014. p. 1-3.

54. Rubin CJ, Zody MC, Eriksson J, Meadows JR, Sherwood E, Webster MT, et al. Whole-genome resequencing reveals loci under selection during chicken domestication. Nature. 2010;464:587-91.

55. Boitard S, Rocha D. Detection of signatures of selective sweeps in the blonde d'Aquitaine cattle breed. Anim Genet. 2013;44:579-83.

56. Monestier O, Brun C, Cocquempot O, Petit D, Blanquet V. GASP/WFIKKN proteins: evolutionary aspects of their functions. PloS One. 2012;7:e43710c

57. Wang J, Zhou H, Fang Q, Luo Y, Hickford JG. Variation in the ovine wfikkn2 gene. Gene. 2014;543:53-7.

58. Zhang YY, Zan LS, Wang HB, Qing L, Wu KX, Quan SA, et al. Differentially expressed genes in skeletal muscle tissues from castrated qinchuan cattle males compared with those from intact males. Livest Sci. 2011;135:76-83.

59. Sheng X, Ni H, Liu Y, Li J, Zhang L, Guo Y. Rna-seq analysis of bovine intramuscular, subcutaneous and perirenal adipose tissues. Mol Biol Rep. 2014:41:1631-7.

Ready to submit your research? Choose BMC and benefit from:

- fast, convenient online submission

- thorough peer review by experienced researchers in your field

- rapid publication on acceptance

- support for research data, including large and complex data types

- gold Open Access which fosters wider collaboration and increased citations

- maximum visibility for your research: over $100 \mathrm{M}$ website views per year

At $\mathrm{BMC}$, research is always in progress.

Learn more biomedcentral.com/submissions 